\title{
PEMIKIRAN DAN GERAKAN MUSLIM PROGRESIF
}

\section{Yusdani}

Dosen Tetap Fakultas 1lmu Agama Islam Universitas Islam Indonesia

Email: yusdani_msi@yahoo.com

DOI: http://dx.doi.org/10.20885/tarbawi.vol8.iss2.art3

\begin{abstract}
This article focuses on Progressive Islam which holds that there is an urgency in the context of today Islam, including in Indonesia, to formulate a set of Islamic values that can be considered as alternative and solutive reference for the creation of a just soceity which respect humanistic values. Therefore, a formulation of a fresh alternative Islamic thought and movement is needed in the context of human life that is relevant with global ethics such as democracy, pluralism, human rights and justice. Therefore, the development of Islamic thought and movement today in the eye of Progressive Islam needs to accommodate the values of equality, justice and humanity. Hence, all citizens have an equal position and access to just treatment, especially the guarantee of religious freedom and minority groups in terms of religion, economy, ethnicity and other aspects are protected equally and justly. The answer of Islam to these various problems of humanity in the eyes of Progressive Islam must be based on the heritage of Islamic knowledge itself using a context-based ijtihad that departs from essential basic Islamic values (maqashid al-shari'ah)
\end{abstract}

Keywords: progressive Islam, Islamic thought and movement

\section{Abstrak}

Pembahasan pokok artikel berikut ini adalah menjelaskan pandangan Islam Progresif yang berpendirian bahwa urgensi dalam konteks Islam dewasa ini termasuk di Indonesia untuk merumuskan seperangkat nilai-nilai Islam yang dapat menjadi referensi alternatif dan solutif bagi terciptanya masyarakat berkeadilan yang menjunjung nilai-nilai kemanu- 
siaan. Oleh karena itu dibutuhkan suatu rumusan pemikiran dan gerakan Islam alternatif yang segar untuk dikembangkan dalam konteks kehidupan manusia yang sesuai dengan etika global seperti demokrasi, pluralisme, HAM dan keadilan sejati kemanusiaan. Karena itu, pengembangan pemikiran dan gerakan Islam sekarang ini dalam pandangan Islam Progresif perlu mangakomodasi nilai-nilai kesetaraan, keadilan, kemanusiaan. Dengan demikian, kedudukan semua warga negara setara dan memperoleh perlakuan yang adil, terutama jaminan kebebasan berkeyakinan, kaum minoritas, baik minoritas dalam segi agama, ekonomi, etnis dan lain-lain dilindungi dan dijamin hak-haknya secara setara dan adil. Jawaban Islam terhadap berbagai persoalan kemanusiaan dewasa ini dalam pandangan Islam Progresif perlu didasarkan dan penggalian khazanah keislaman itu sendiri dengan mempergunakan context-based ijtibad (progressive ijtihadist) yang bertitik-tolak dari nilai-nilai dasar Islam yang esensial (maqasid syariab).

Kata Kunci: Islam progresif, pemikiran dan gerakan Islam

\section{Pendahuluan}

Dalam upaya untuk merumuskan pemikiran dan solusi alternatif atas berbagai persoalan yang dihadapi dunia muslim dewasa ini, telah memunculkan berbagai aliran pemikiran keagamaan (Islam), seperti aliran konservatif, aliran liberal, aliran moderat, dan lain-lain. Salah satu tren pemikiran yang muncul di era kontemporer sekarang ini adalah The Progressive Ijtihadists, atau Rational Reformism, yaitu pemikiran muslim yang berupaya menafsir ulang ajaran agama (Islam) agar bisa menjawab kebutuhan masyarakat masa kini (Saeed, 2006: 142-150).

Meskipun substansinya tidak jauh berbeda dengan terma-terma lain, seperti Islam Inklusif, Islam Transformatif dan Islam Progresif (Progressive Islam) merupakan istilah baru dalam kajian Islam kontemporer yang digunakan oleh para akademisi dan aktivis sejak beberapa tahun ini untuk memberikan label kepada pemahaman-pemahaman dan aksi-aksi umat Islam yang memperjuangkan penegakan nilai-nilai humanis, seperti pengembangan civil society, demokrasi, keadilan, kesetaraan gender, pembelaan terhadap kaum minoritas, kaum tertindas dan pluralitas (Ramadhan, 2004: 24-28).

Di satu sisi pandangan dan aksi Islam Progresif, merupakan kelanjutan dan kepanjangan dari gerakan Islam Liberal yang muncul sejak 
kurang lebih seratus lima puluh tahun yang lalu. Namun di sisi lain, ia muncul sebagai ungkapan ketidakpuasan terhadap gerakan Islam Liberal yang lebih menekankan pada kritik-kritik internal terhadap pandangan dan perilaku umat Islam yang tidak atau kurang sesuai dengan nilainilai humanis. Sementara itu, kritik terhadap modernitas, kolonialisme, dan imperialisme justru tidak mendapatkan perhatian yang cukup dari gerakan Islam Liberal (Omid Safi, "What is Progressive Islam?". Dalam www.muslimwakeup.com/main/archieves/2005/04/what_is_progres_1. php accessed 7 Juli 2014).

Realitas di atas itulah yang memberikan inspirasi terhadap munculnya pemahaman dan aksi Islam Progresif, yang memberikan perhatian seimbang antara kritik internal dan kritik eksternal. Kritik internal terhadap tradisi pemikiran sebagian umat Islam yang tidak menitikberatkan pada aspek-aspek kehidupan humanis, memposisikan gerakan Islam Progresif pada gerakan modernis, namun pada waktu yang bersamaan ia juga merupakan gerakan postmodernis/neomodernis karena ia juga bersikap kritis terhadap modernitas yang bertentangan dengan nilai-nilai keadilan sejati dan kemanusiaan. Cara pandang kritis dan aksi Islam Progresif semuanya hendaknya berorientasi kepada kemajuan. Atas dasar inilah ia disebut dengan istilah progresif (Noor, 2006: 23). Pokok pembahasan tulisan singkat ini lebih terfokus pada pengenalan karakteristik pemikiran Islam Progresif dan relevansinya dengan konteks kehidupan muslim dewasa ini.

\section{Karakteristik Islam Progresif}

Karakteristik menonjol yang dimiliki oleh muslim progresif di atas adalah:

1. Mereka mengadopsi pandangan bahwa beberapa bidang Islam tradisional membutuhkan perubahan dan reformasi substansial dalam rangka menyesuaikan dengan kebutuhan masyarakat muslim saat ini.

2. Mereka cenderung mendukung akan perlunya fresh ijtihad (pemikiran yang segar) dan metodologi baru dalam ijtihad untuk menjawab permasalahan-permasalahan kontemporer.

3. Beberapa di antara mereka juga mengkombinasikan atau mengintegrasikan secara kreatif warisan kesarjanaan Islam tradisional dengan pemikiran Barat modern. 
4. Mereka secara penuh optimis dan teguh berkeyakinan bahwa dinamika dan perubahan sosial, baik pada ranah intelektual, moral, hukum, ekonomi atau teknologi, dapat direfleksikan dalam Islam.

5. Mereka tidak merasa terikat pada dogmatisme atau mazhab dan teologi tertentu dalam pendekatan kajiannya.

6. Mereka lebih meletakkan titik tekan pemikirannya pada berbagai isu keadilan sosial, keadilan gender, HAM dan relasi yang harmonis antara Muslim dan non-Muslim (Noor, 2006: 150-151).

Lebih jauh dapat diuraikan sepuluh kriteria yang lebih bersifat teknis dari gerakan yang membedakan muslim progresif dengan lainnya, yaitu bahwa pemikiran muslim progresif memiliki pandangan dan keyakinan sebagai berikut:

1. Rasa nyaman (comfort) ketika menafsir ulang atau menerapkan kembali Islam dengan mengacu prinsip-prinsip dasar Islam.

2. Keadilan gender adalah ditegaskan dalam Islam.

3. Semua agama secara inheren adalah sama dan harus dilindungi secara konstitusional.

4. Semua manusia juga setara dan sama.

5. Keindahan merupakan bagian inheren dari tradisi Islam baik yang ditemukan dalam seni, arsitektur, puisi maupun musik.

6. Dukungan atas kebebasan berbicara, berkeyakinan dan berserikat.

7. Menunjukkan kasih sayang pada semua makhluk.

8. Hak "orang lain" itu ada dan perlu dihargai.

9. Sikap moderat dan anti-kekerasan dalam menyelesaikan permasalahan masyarakatnya.

10. Antusiasme yang tinggi terhadap isu-isu yang berkaitan dengan peran agama dalam tataran public (Safi, 2003: 10).

Nilai keadilan, kebaikan dan keindahan adalah nilai-nilai universal Islam yang menjadi jiwa semua aspek keislaman. Oleh karena itu, semua ketentuan dan status hukum Islam tradisional yang tidak berpihak pada keadilan, kebaikan dan keindahan haruslah ditinggalkan untuk kemudian diganti dengan ketentuan hukum yang sesuai dengan prinsip universal Islam dengan menggunakan pendekatan progressive ijtihadi. 
Dengan cara seperti itulah Islam mampu eksis dan hidup dalam percaturan dunia dan mampu menjawab persoalan-persoalan kontemporer seperti masalah hak-hak asasi manusia, pluralisme dan lain sebagainya. Dalam bahasa Omid Safi, apa yang dilakukan oleh muslim progresif adalah "is not so much an epistemological rupture from what has come before as a fine-tuning, a polishing, a grooming, an editing, a re-emphasizing of this and a correction of that" (Safi, 2003: 16).

Berdasarkan uraian di atas, jelaslah bahwa progressive ijtibadists menjadi kerangka pemikiran Islam Progresif. Kerangka pemikiran seperti ini tidaklah berarti menciptakan sebuah agama atau ajaran baru melainkan mencoba mere-interpretasi fondasi religius tradisional untuk mengakomodasi kehidupan kontemporer, terutama dalam menjawab isuisu kehidupan muslim masa kini.

Operasionalisasi ijtihad yang dilakukan oleh muslim progresif yang telah diutarakan di atas merupakan salah satu dari tiga model ijtihad yang sangat berpengaruh pada masanya masing-masing sepanjang sejarah Islam, yaitu: Pertama adalah text-based ijtihad, yakni metode pemikiran (ijtihad) yang lazim dilakukan oleh pemikir muslim klasik dan tengah serta masih memiliki banyak pengaruh di kalangan pemikir tradisionalis. Model pemikiran (ijtihad) seperti ini teks berkuasa penuh (textual-oriented approach), baik itu Alqur'an, Hadis ataupun pendapat ulama sebelumnya baik yang berupa ijma' ataupun qiyas.

Kedua adalah eclectic ijtihad, yakni upaya memilih teks atau pendapat ulama sebelumnya yang paling mendukung pendapat dan posisi yang diyakininya. Dalam hubungan ini yang ada adalah upaya justifikasi bukan pencarian kebenaran, Ketiga adalah context-based ijtihad, (maqasid alsyari'ab-based ijtihad) sebuah fenomena baru yang mencoba memahami masalah-masalah Islam dalam konteks kesejarahan dan konteks kekiniannya. Pada umum dan biasanya, pendapat akhirnya akan mengacu pada kemaslahatan umum sebagai maqasid al-syari'ah (Saeed, 2006: 55).

Dari tiga model ijtihad yang dikemukakan di atas, ijtihad model ketiga merupakan pilihan dan alternatif yang dilakukan oleh para Progressive Ijtihadists. Kalau metodologi era klasik dan tengah biasanya memecahkan permasalahan Islam seperti hukum dengan mendasarkannya pada teks Alquran, kemudian memahami apa yang dikatakan teks tentang permasalahan tersebut, dan paling jauh adalah kemudian menghubungkan 
teks itu dengan konteks sosio-historisnya (Sulayman, 1993: 87-94).

Sementara itu Progressive Ijtihadists mencoba lebih jauh lagi menghubungkannya dengan konteks kekinian sehingga tetap up to date dan dapat diterapkan. Model seperti inilah sesungguhnya yang dilakukan oleh para pemikir muslim kontemporer, antara lain Aminah Wadud, Tariq Ramadan, Muqtader Khan, Bassam Tibi, Farid Esack, Ebrahim Moosa, Irshad Manji, Fazlur Rahman, Khaled Abou el Fadl, dan lain sebagainya (Sulayman, 1993: 94).

Berkaitan dengan bagaimana metodologi Progressive Ijtibadists menafsir ulang teks-teks Alquran, dapat dipaparkan ada tujuh pendekatan utama, yaitu:

1. Adanya atensi pada konteks dan dinamika sosio-historis.

2. Menyadari bahwa ada beberapa topik yang tidak dicakup oleh Alquran karena waktunya belum tiba pada waktu diturunkannya Alquran.

3. Menyadari bahwa setiap pembacaan atas teks kitab suci harus dipandu oleh prinsip kasih sayang, justice dan fairness.

4. Mengetahui bahwa Alquran mengenal hirarki nilai-nilai dan prinsip.

5. Mengetahui bahwa dibolehkan berpindah dari satu contoh yang konkret pada generalisasi atau sebaliknya.

6. Kehati-hatian harus dilakukan ketika menggunakan teks lain dari tradisi klasik, khususnya yang berkaitan dengan otentisitasnya.

7. Fokus utama pada kebutuhan muslim kontemporer (IDSS: 5).

Tantangan, kendala atau hambatan sebagaimana dikemukakan oleh Abdullah Saeed, anggapan bahwa hanya ada satu set Islam yang dapat diterima sebagai kebenaran tunggal dan lainnya dianggap salah. Kendala truth claim (klaim kebenaran) ini masih dominan di kalangan umat Islam. Dalam bahasa lain, seperti dungkapkan oleh Engineer yang menyatakan bahwa key obstacle terletak pada internal umat, yaitu hilangnya kebebasan dan tiadanya demokrasi. Dalam hubungan ini, Chandra Muzaffar menyebutkan empat kendala penyebaran ide-ide Islam progresif, yaitu:

Pertama adalah yang direpresentasikan oleh kelompok muslim konservatif yang menebarkan ide-idenya dengan menggunakan kekerasan. Kedua adalah yang ditunjukkan oleh karya intelektual muslim 
yang mengklaim peduli pada masa depan Islam tetapi yang dilakukan adalah membungkus ide lama dengan pakaian baru (refasbioning Islam). Ketiga adalah perilaku atau tindakan negara-bangsa yang represif, dan, keempat adalah apa yang ditunjukkan oleh global system of power yang tidak memberi peluang perbedaan pendapat dalam mendiskusikan isu-isu sosial ekonomi (Laporan Seminar dengan tema Civil and Political Rights (Pundamental Liberties), MIEHRI, Hotel Hilton Malaysia tanggal 16 Mei 2006, hlm. 74).

Terlepas dari kendala atau hambatan tersebut, ide-ide Islam Progresif, terus berjalan menciptakan equilibrium pemikiran keislaman. Bahkan, ide Islam Progesif ini bukan hanya bersentuhan dengan nilai-nilai universal seperti keadilan dan kebebasan yang menjadi wacana unggulan kontemporer, melainkan masuk pada wilayah-wilayah hukum Islam. Munculnya istilah Progressive Ijtihadi yang meniscayakan penafsiran ulang teks-teks hukum dan pembingkaian ulang metode penetapan hukum sehingga sifat fleksibilitas dan elastisitas hukum Islam yang dicanangkan oleh para mujtahid masa lalu tidak hanya terekam dan tertulis dalam kitab -kitab kuning melainkan menjadi kenyataan sehari-hari.

Salah seorang tokoh yang menonjol dalam konteks Islam Progresif ini sebagai jurubicaranya adalah Abdullah Saeed. Abdullah Saeed adalah cendekiawan yang berlatar belakang pendidikan bahasa dan sastra Arab serta studi Timur Tengah yang sangat baik. Kombinasi institusi pendidikan yang diikuti, yaitu pendidikan di Saudi Arabia dan Australia menjadikannya kompeten untuk menilai dua dunia, Barat dan Timur, secara objektif.

Abdullah Saeed sangat concern dengan dunia Islam kontemporer. Pada dirinya ada spirit bagaimana ajaran-ajaran Islam itu bisa salib $f$ kulli zaman wa makan. Spirit semacam inilah yang ia sebut dengan Islam Progresif, subjeknya dikenal dengan Muslim Progresif, upaya untuk mengaktifkan kembali dimensi progresif Islam yang dalam kurun waktu cukup lama mati suri ditindas oleh dominasi teks (Coulson, 1996: 41). Metode berfikir yang digunakan oleh muslim progresif inilah yang disebutnya dengan istilah progressive ijtihadi.

Sebagaimana diakui oleh Abdullah Saeed bahwa pola pikir Progressive Ijtihadi ini masih menghadapi banyak kendala. Kendala yang paling besar adalah kendala internal, seperti ketidaksiapan umat Islam sendiri untuk berbeda pendapat yang disertai kesenangannya pada budaya 
takfir yang bermula dari truth claim. Tidak sedikit sarjana muslim yang memandangnya secara sinis ataupun bahkan dianggap sebagai sebuah penyimpangan dari Islam yang asli.

Sesungguhnya, menurut Abdullah Saeed, muslim progresif ini merupakan perkembangan lanjutan dari tren modernis, yang berkembang menjadi neo-modernis dan kemudian menjadi progresif. Sebagai tren, muslim progresif ini menampung semua kelompok dan kalangan yang memiliki keberpihakan pada nilai-nilai universal Islam sehingga mampu menjawab kebutuhan masyarakat modern. Omid Safi menyebutkan beberapa isu penting yang harus dijawab oleh muslim progresif, antara lain adalah ketidakadilan gender, deskriminsasi terhadap kelompok minoritas baik minoritas agama ataupun etnis (Auda, 2008: 177-179), pelanggaran hak asasi manusia, tiadanya kebebasan berbicara, berkeyakinan dan mempraktikkan agama sendiri, pembagian kekayaan yang tidak merata, dan pemerintahan yang otoriter (Safi, 2003: 2-3).

Ketika Abdullah Saeed ditanya siapakah yang paling berhak untuk menafsirkan Islam, yang paling berperan menyalurkan warna interpretasi Islam, dia menjawab: "although Islam does not have a clergy or a centralized church structure, Muslim religious establishments exert considerable influence in terms of how Muslims view and practice their religion. If they are antithetical to progressive Islam, their constituences would be averse to it as well" (IDSS:14).

\section{Kontribusi, Posisi dan Relevansi Islam Progresif}

Berdasarkan penjelasan tentang kerangka metodologi, isu dan tantangan Islam Progresif di atas, adalah sangat dapat dimengerti bila dikatakan bahwa kemunduran yang dialami oleh Islam dewasa ini diduga kuat juga disebabkan oleh kurang relevannya perangkat teoritik kajian Islam untuk memecahkan problem kontemporer (An-Naim). Dalam perjalanan historisnya kajian Islam lebih bercorak teologis-deduktif atau paradigma literalistik dalam arti begitu dominannya pembahasan tentang teks, dan cenderung mengabaikan pembahasan tentang maksud dasar (substantif etis) dari wahyu yang ada di balik teks literal (M. Amin Abdullah, "A1Ta'wil al-'Ilmi: Ke Arah Perubahan Paradigma Penafsiran Kitab Suci," Al-Jami'ah, vol. 39, 2.2001.359-391).

Dengan demikian, dapat dimengerti bila dikatakan bahwa kemunduran yang dialami oleh Islam dewasa ini diduga kuat juga disebabkan oleh kurang relevannya perangkat teoritik keilmuan Islam 
untuk memecahkan problem kontemporer. Paradigma literalistik berlangsung selama kurang lebih lima abad (dari abad ke-2 $\mathrm{H}$ sampai abad ke-7 H) dan baru mengalami perbaikan dengan munculnya asySyatibi pada abad ke-8 H yang menambahkan teori maqasid as-syariab yang mengacu pada maksud Allah yang paling dasar (Syari, Lawgiver). Enam abad kemudian, sumbangan asy-Syatibi pada abad ke-8H/14M itu, direvitalisasikan oleh para pemikir modern, seperti Muhammad Abduh , Rasyid Rida, Abdul Wahhab Khallaf, 'Allal al-Fasi dan Hasan Turabi (Muhammad, 86).

Karena tidak menawarkan teori baru terkecuali merevitalisasi prinsip kepentingan umum (maslahab) yang ditawarkan as-Syatibi melalui teori maqasid-nya itu, karena itu kelompok ini disebut sebagai penganut aliran utilitarianisme (Hallaq, 1987). Sementara itu, pertanyaan tentang bagaimanakah teks suci dapat dipahami dan kemudian dijalankan dalam konteks dunia modern yang sudah barang tentu tidak lagi sama dengan konteks zaman Nabi tetap saja masih menjadi agenda besar bagi umat Islam dewasa ini. Pertanyaan semacam ini menurut sebagian pakar seperti Muhammad Iqbal, Muhammad Taha, Abdullahi Ahmed Na'im, Muhammad Said Ashmawi, Fazlur Rahman, dan Muhammad Syahrur, sama sekali tidak dapat diselesaikan dengan berpijak pada prinsip maslahah klasik di atas.

Bahkan mereka beranggapan bahwa prinsip kepentingan umum (maslahah) tidak lagi memadai untuk membuat Islam mampu hidup di dunia modern. Dengan mengambil sampel tiga orang pemikir (Muhammad Abied al-Jabiri, Fazlur Rahman dan Syahrur), kelompok ini dinamakan aliran liberalisme keagamaan (religious liberalism-atau liberalistik fenomenologik), karena coraknya yang liberal dan cenderung membuang teori-teori lama. Pembaruan yang ditawarkan dari kelompok ini dianggap lebih menjanjikan dan lebih persuasif.

Kelompok ini dalam rangka membangun metodologinya yang ingin menghubungkan antara teks suci dan realitas dunia modern lebih berpijak pada upaya melewati makna eksplisit teks untuk menangkap jiwa dan maksud luas dari teks. Akan tetapi bagaimanapun juga, tawaran pembaharuan Usul oleh mereka yang disebut dengan kaum liberalis itu tetap saja menyisakan sejumlah kontroversi dan perdebatan. Tawaran itu hingga saat ini masih dianggap oleh mayoritas ulama Usul secara negatif bahkan penuh kecurigaan. Akar utama penyebab kontroversi ini adalah 
karena tawaran mereka tidak memiliki landasan kuat pada kerangka teoritik (Theoritical frame) ilmu Usul yang telah ada sebelumnya. Padahal perkembangan suatu ilmu tidak harus berjalan secara evolutif yang selalu berpijak pada teori lama tetapi bisa saja dengan cara revolutif, di mana sama sekali tidak berpijak pada teori-teori yang telah ada sebelumnya, tetapi menawarkan sebuah paradigma yang sama sekali baru. Perkembangan ilmu semacam ini disebut "gestalt swich" atau "gestalt shift" alias pergeseran paradigma (paradigm shift) yang sangat dikenal dalam filsafat ilmu pengetahuan kontemporer (Kuhn, 1970: 121).

Uraian di atas merupakan dasar pijak yang kuat dan urgensi kehadiran pemikiran dan gerakan Islam Progresif bertujuan merumuskan Islam yang dapat menjadi referensi dasar bagi terciptanya masyarakat berkeadilan yang menjunjung nilai-nilai kemanusiaan, meratanya nuansa kerahmatan dan kebijaksanaan, serta terwujudnya kemaslahatan bagi seluruh umat manusia.

Dengan kata lain kehadiran Islam Progresif merupakan suatu rumusan baru Islam yang sesuai dengan kehidupan demokrasi. Di dalam pemikiran Islam seperti ini semua warga negara mempunyai kedudukan yang sama dan memperoleh perlakuan yang adil, kaum minoritas dilindungi dan dijamin hak-haknya secara setara.

Oleh karena itu, transformasi Islam dalam pandangan Islam Progresif adalah identik dengan sosial kemanusiaan Islam dan Demokrasi, selain akan mengantarkan Islam dapat diterima oleh semua kalangan, juga kompatibel dengan kehidupan demokrasi. Dengan demikian nalar pembentukan Islam Progresif berperspektif demokrasi, pluralisme, dan HAM. Oleh karena itu, Islam sekarang ini harus mengakomodasi dan mencerminkan kesetaraan, keadilan, kemanusiaan, dan menjamin kemaslahatan.

Berpangkal tolak dari penjelasan di atas dapat dipahami bahwa prinsip-prinsip dasar Islam perlu mengapresiasi pluralisme (ta'addudiyab), nasionalitas (muwatanah), penegakan HAM ((iqamat al-huquq alinsaniyah), demokrasi (dimuqratiyah), kemaslahatan (maslahat), dan kesetaraan gender (al-musawah al-jinsiyah). Sedangkan alur penafsiran ajaran Islam seperti ini adalah Alquran \& al-Hadis, kemaslahatan, maqasid al-syari'ah, dan akal publik.

Tawaran pemikiran di atas berbeda dengan pemikiran Islam 
konservatif pada umumnya, karena menggunakan nalar pemahaman Islam yang mengaitkan penafsiran teks-teks Alquran dan al-Hadis dengan perspektif demokrasi, pluralism, hak asasi manusia dan dibahasakan sesuai dengan aturan perundang-undangan yang berlaku dalam konteks dunia muslim kontemporer. Selain itu, tawaran pemikiran di atas sekalipun kontroversial, dan mungkin ditolak oleh kelompok pendukung formalisasi Islam (Syari'at Islam). Namun demikian, kehadiran pemikiran seperti ini diimaksudkan sebagai alternatif formalisasi Islam sehingga Islam kompatibel dengan kehidupan demokrasi dan kondisi kontemporer.

Penolakan atas pemikiran Islam Progresif di atas oleh kelompok pendukung formalisasi Islam di Indonesia disebabkan ketidaksiapan kelompok-kelompok tersebut dalam menerima perspektif demokrasi, pluralisme, hak asasi manusia (Marzuki, 2011: 432), sebagai etika global kehidupan masyarakat kontemporer yang tidak dapat dihindari dan bahkan perlu memberikan kontribusinya. Sedangkan di sisi lain sebagian tawaran pemikiran secara prinsip berbeda dengan keumuman pemahaman ajaran Islam yang dianut masyarakat.

\section{Catatan Penutup}

Sebagai penutup dari keseluruhan pembahasan terdahulu makalah ini dapat dikemukakan beberapa hal sebagai berikut:

1. Bahwa Islam Progresif (Progressive Islam) merupakan kajian Islam kontemporer yang memperjuangkan penegakan nilainilai humanis, seperti pengembangan civil society, demokrasi, keadilan, kesetaraan gender, pembelaan terhadap kaum minoritas, kaum tertindas dan pluralitas. Ia merupakan kelanjutan dan kepanjangan dari gerakan Islam Liberal. Namun di sisi lain, ia muncul sebagai ungkapan ketidakpuasan terhadap gerakan Islam Liberal yang lebih menekankan pada kritik-kritik internal terhadap pandangan dan perilaku umat Islam yang tidak atau kurang sesuai dengan nilai-nilai humanis. Sementara itu, kritik terhadap modernitas, kolonialisme, dan imperialisme justru tidak mendapatkan perhatian yang cukup dari gerakan Islam Liberal. Islam Progresif, memberikan perhatian seimbang antara kritik internal dan kritik eksternal. Kritik internal terhadap tradisi pemikiran sebagian umat Islam yang tidak menitikberatkan pada aspek-aspek kehidupan 
humanis. Gerakan Islam Progresif diposisikan sebagai gerakan modernis, namun pada waktu yang bersamaan ia juga merupakan gerakan postmodernis/neomodernis karena ia juga bersikap kritis terhadap modernitas yang bertentangan dengan nilai-nilai keadilan sejati dan kemanusiaan.

2. Bahwa kehadiran pemikiran dan gerakan Islam Progresif dan urgensinya dalam konteks Islam dewasa ini adalah bertujuan merumuskan seperangkat pemikiran dan gerakan Islam yang dapat menjadi referensi alternatif dan solutif bagi terciptanya masyarakat berkeadilan yang menjunjung nilai-nilai kemanusiaan. Dengan kata lain suatu rumusan baru pemikiran yang sesuai dengan kehidupan masyarakat kontemporer dewasa ini.

3. Bahwa nalar pembentukan Islam Progesif berperspektif demokrasi, pluralisme, dan HAM. Oleh karena itu, pengembangan pemikiran dan gerakan Islam dewasa ini harus mencerminkan dan mangakomodasi nilai-nilai kesetaraan, keadilan, kemanusiaan.

4. Bahwa dalampemikirandangerakanIslam Progresifkedudukan semua warga negara setara (equal) dan memperoleh perlakuan yang adil, terutama jaminan kebebasan berkeyakinan, kaum minoritas, baik minoritas dalam segi agama, ekonomi, etnis dan lain-lain dilindungi dan dijamin hak-haknya secara setara dan adil. Oleh karena itu, dalam pandangan Islam Progresif transformasi Islam selain akan mengantarkan Islam dapat diterima publik dan semua kalangan, juga kompatibel dengan tuntutan kehidupan masyarakat kontemporer. 


\section{Daftar Pustaka}

Abdullah, M. Amin.2001. "Al-Ta'wil al-'Ilmi: Ke Arah Perubahan Paradigma Penafsiran Kitab Suci,” Al-Jami’ah, vol. 39, 2. 2001.hlm. 359-391.

Asymawi, Muhammad Said.1983. Usul asy-Syari'ah. Beirut: Dar Iqra'.

Auda, Jasser. 2008. Maqasid al-Syariah as Philosophy of Islamic Law: A System Approach. London, IIIT.

Bayyah, Syaikh Abdullah ibn Syaikh al-Mahfuz bin.2007. Sina'at alFatawa wa Fiqh al-Aqalliyah .Beirut: Dar al-Minhaj.

Coulson, N. J. .1964. A History of Islamic Law .Edinburgh: Edinburgh University Press.

Fasi, 'Allal al-..1963. Maqashid as-Syari'ah al-Islamiyyah wa Makarimuba, Casablanca: Maktabah al-Wahdah al-'Arabiyah.

Hallaq, Wael B..1987. A. History of Islamic Legal Theories: An Introduction to Sunni Usul Figh, Cambridge: Cambridge University Press.

Imarah, Muhammad (ed).1972. ' al-Amal al-Kamilah li al-Imam Muhammad 'Abduh, Beirut: Al-Mu'assasah al-'Arabiyah li adDirasah wa an-Nasyr.

Iqbal, Mohammad.1971. The Reconstruction of Religious Thought in Islam. Lahore: Ashraf Press.

Khadduri, Majid.1966. "From Religion to National Law," dalam J. Thompson dan R. Reischauer (Eds), Modernization of the Arab World. New York: Van Nostrand, hlm. 41.

Khallaf, Abdul Wahhab.1955. Mashadir at-Tasyri' fi ma la Nashsha fih. Kairo: Dar al-Kitab al-Arabi.

Khun, Thomas S..1970. The Structure of Scientific Revolutions. Chicago: The University of Chicago Press.

Laporan Seminar dengan tema Civil and Political Rights (Pundamental Liberties), MIEHRI, Hotel Hilton Malaysia tanggal 16 Mei 2006, hlm. 74.

Marzuki, Suparman.2011. Tragedi Politik Hukum HAM . Yogyakarta: PUSHAM UII dan Pustaka Pelajar. 
Na'im, Abdullahi Ahmed an-.1990.Toward an Islamic Reformation: Civil Liberties, Human Rights, and International Law. Syracus: Syracus University Press.

Noor, Farish A. 2006. Islam Progresif: Peluang, Tantangan, das Masa Depannya di Asia Tenggara. Terj. Moch. Nur Ichwan dan Imron Rosyadi. Yogyakarta: SAMHA.

Rahman, Fazlur. 1979. “Toward Reformulating the Methodology of Islamic Law: Sheikh Yamani on Public International on Islamic Law" dalam New York University Journal of International Law and Politics 12 (1979): 219-24.

Ramadan, Tariq. 2004. Western Muslims and the Future of Islam. New York: Oxford University Press.

Saeed, Abdullah. 2002. 'Jihad and Violence: Changing Understanding of Jihad among Muslims' dalam Tony Coady and Michael O'Keefe (eds). Terrorism and Violence.Melbourne: Melbourne University Press.

2006. Interpreting the Qur'an: Towards a Contemporary Approach. London: Routledge.

Routledge.

Islamic Thought An Introduction. London and New York:

. Muslims in the West Choose Between Isolationism and Participation' dalam Sang Seng vol 16. Seoul: Asia-Pacific Centre for Education and International Understanding/ UNESCO.

'Muslims in the West and their Attitudes to Full Participating in Western Societies: Some Reflections' dalam Geoffrey Levey (ed.). Religion and Multicultural Citizenship. Cambridge: Cambridge University Press.

Safi, Omid "What is Progressive Islam?". Dalam www.muslimwakeup.com/main/archieves/2005/04/what_is_ progres_1.php accessed 7 Juli 2014.

Safi, Omid.2003. "What is Progressive Islam," dalam The International Institute for the Study of Islam in the Modern World (ISIM) News Letter, No.13, Desember 2003, hlm. 10. 
Subki, Ali. b. Abd. Al-Kafi as-..1995.al-Ibhajfi Syarb al-Minhaj. Beirut: Dar al-Kutub al-Ilmiyah.

Sulayman, Abdul Hamid A..1993.Towards ad Islamic Theory of International Relations: New Direction for Methodology and Thought. Herdon, Virginia:IIIT, 1993. h1m. 87-94.

Syahrur, Muhammad.1992. al-Kitab wa al-Qur'an: Qira'ah Mu'asirah. Damaskus: al-Ahab li ath-Thiba'ah li an-Nasyr wa at-Tauzi.

Syamsuddin, Sahiron, "Islam Progresif dan Upaya Membumikannya di Indonesia” dikutip dari http://nahdliyinbelanda.wordpress. com/2007/09/29/islam-progresif-dan-upaya-membumikannya-diindonesia/ accessed 7 Juli 2014.

Taha, Mahmud Mohammad.1987. ar-Risalah as-Saniah min al-Islam. Terj. Abdullahi Ahmed an-Na'im ke dalam bahasa Inggris The Second Message of Islam. Syracuse: Syracuse University Press.

Turabi, Hasan.1956. Yusr al-Islam wa Usul at-Tasri' al-Am. Kairo: Mathba'ah Nahdah Mishr.

1980. Tajdid Usul al-Figh, Beirut and Khortoum: Dar al-Fikr, 1980.

.1993. Tajdid al-Fikr al-Islami, Rabat: Dar al-Qarafi li anNasyr wa at-Tauzi'.

Yusdani.2011.”Menguji Kompatibilitas HAM dan Syari'ah”,Makalah disampaikan dalam Workshop Does Shari'a Protect and Promote Human Rights? Concepts and Practices in Contemporary Indonesia yang diselenggarakan oleh PSI UII dan NCHR, Kamis, 10 November 2011 di Hotel Jayakarta, Jl.Laksda Adisucipto, km 8. Yogyakarta.

. 2012."Agama dan Isu-Isu Kontemporer Perspektif Fiqh Progresif" dalam al-Mawarid Jurnal Hukum Islam FIAI UII.

. 2014. "Islam dan Isu-Isu Kemanusiaan Kontemporer Perspektif Islam Progresif" Makalah pengantar diskusi disampaikan dalam Forum Kajian Islam Progresif Social Movement Institut (SMI) berkerjasama dengan Majelis Pemberdayaan Muhammadiyah (MPM) serta Dema Fisip UGM Jumat, 11 Juli 2014 di Kantor SMI. Jl. Tanjung. No 64 Sorogenen.

. 2015. Menuju Fiqh Keluarga Progresif. Yogyakarta: Kaukaba. 